ҚАЗАҚСТАН РЕСПУБЛИКАСЫ

ҰЛТТЫҚ ҒЫЛЫМ АКАДЕМИЯСЫНЫН

АБАЙ АТЫНДАҒЫ ҚАЗАҚ ҰЛТТЫҚ

ПЕДАГОГИКАЛЫҚ УНИВЕРСИТЕТІНІҢ

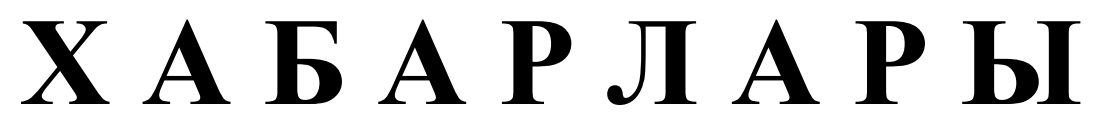

\section{ИЗВЕСТИЯ}

НАЦИОНАЛЬНОЙ АКАДЕМИИ НАУК РЕСПУБЛИКИ КАЗАХСТАН

КАЗАХСКИЙ НАЦИОНАЛЬНЫЙ

ПЕДАГОГИЧЕСКИЙ УНИВЕРСИТЕТ ИМ. АБАЯ

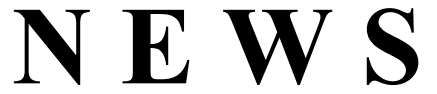

OF THE NATIONAL ACADEMY OF SCIENCES OF THE REPUBLIC OF KAZAKHSTAN

ABAY KAZAKH NATIONAL PEDAGOGICAL UNIVERSITY

ҚОҒАМДЫҚ ЖӘНЕ ГУМАНИТАРЛЫҚ ҒЫЛЫМДАР СЕРИЯСЫ

СЕРИЯ ОБЩЕСТВЕННЫХ И ГУМАНИТАРНЫХ НАУК

$\checkmark$

SERIES OF SOCIAL AND HUMAN SCIENCES

$$
5 \text { (321) }
$$

КЫРКУЙЕК - КАЗАН 2018 ж.

СЕНТЯБРЬ - ОКТЯБРЬ 2018 Г.

SEPTEMBER - OCTOBER 2018

1962 ЖЫЛДЫҢ ҚАНТАР АЙЫНАН ШЫҒА БАСТАҒАН

ИЗДАЕТСЯ С ЯНВАРЯ 1962 ГОДА

PUBLISHED SINCE JANUARY 1962

ЖЫЛЫНА 6 РЕТ ШЫҒАДЫ

ВЫХОДИТ 6 РАЗ В ГОД

PUBLISHED 6 TIMES A YEAR 
Ба с ре дактор

ҚР ҰҒА кұрметті мүшесі

Балықбаев Т.O.

Р е д а ц и я а лқ а сы:

экон. ғ. докторы, проф., ҚР ҰҒА академигі Баймұратов У.Б.; тарих ғ. докторы, проф., ҚР ҰҒА академигі Байпақов К.М.; филос. ғ.докторы, проф., ҚР ҰҒА академигі Есім Г.Е.; фил. ғ. докторы,, проф., ҚР ҰҒА академигі Қирабаев С.С.; эк. ғ. докторы, проф., ҚР ҰҒА академигі Кошанов А.К.; эк.ғ. докторы, проф., ҚР ҰҒА академигі Нәрібаев К.Н. (бас редактордың орынбасары); филос. ғ.докторы, проф., ҚР ҰҒА академигі Нысанбаев А.Н.; заң ғ. докторы, проф., ҚР ҰҒА академигі Сәбікенов С.Н.; заң ғ. докторы, проф., ҚР ҰҒА академигі Сүлейменов М.К.; эк. ғ. докторы, проф., ҚР ҰҒА академигі Сатыбалдин С.С.; тарих ғ. докторы, проф., ҚР ҰҒА академик Әбжанов Х.М.; тарих ғ. докторы, проф., ҚР ҰҒА корр. мүшесі Әбусеитова М.Х.; тарих ғ. докторы, проф., ҚР ҰҒА академик Байтанаев Б.А.; филол. ғ. докторы, проф., ҚР ҰҒА корр. мүшесі Жақып Б.А.; фил. ғ. докторы, проф., академик НАН РК Қалижанов У.К.; филол. ғ. докторы, проф., ҚР ҰҒА академик Қамзабекұлы Д.; тарих ғ. докторы, проф., ҚР ҰҒА академик Қожамжарова Д.П.; тарих ғ. докторы, проф., ҚР ҰҒА академик Койгелдиев М.К.; фил. ғ. докторы, проф., ҚР ҰҒА корр. мүшесі Кұрманбайұлы Ш.; тарих ғ. докторы, проф., ҚР ҰҒА корр. мүшесі Таймағанбетов Ж.К.; социол. ғ. докторы, проф., ҚР ҰҒА корр. мүшесі Шәукенова 3.К.; фил. ғ. докторы, проф., КР ҰҒА корр. мүшесі Дербісәлі А.; саяси. ғ. докторы, проф., Бижанов А.К., тарих ғ. докторы, проф., Кабульдинов 3.Е.; фил. ғ. докторы, проф., ҚР ҰҒА корр мүшесі Қажыбек Е.3.

\section{Р едакция ке н е с i:}

Молдова Республикасының ҰҒА академигі Белостечник Г. (Молдова); Әзірбайжан ҰҒА академигі Велиханлы Н. (Азербайджан); Тәжікстан ҰҒА академигі Назаров Т.Н. (Тәжікстан); Молдова Республикасының ҰҒА академигі Рошка А. (Молдова); Молдова Республикасының ҰҒА академигі Руснак Г. (Молдова); Әзірбайжан ҰҒА корр. мүшесі Мурадов Ш. (Әзірбайжан); Әзірбайжан ҰҒА корр. мүшесі Сафарова 3. (Әзірбайжан); э. ғ. д., проф. Василенко В.Н. (Украина); заң ғ. докт., проф. Устименко В.А. (Украина)

«Қазақстан Республикасы Ұлттық ғылым академиясының Хабарлары. Қоғамдық және гуманитарлық ғылымдар сериясы». ISSN 2224-5294

Меншіктенуші: «Қазақстан Республикасының Ұлттық ғылым академиясы» РҚБ (Алматы қ.)

Қазақстан республикасының Мәдениет пен ақпарат министрлігінің Ақпарат және мұрағат комитетінде 30.04.2010 ж. берілген № 10894-Ж мерзімдік басылым тіркеуіне қойылу туралы куәлік

Мерзімділігі: жылына 6 рет.

Тиражы: 500 дана.

Редакцияның мекенжайы: 050010, Алматы қ., Шевченко көш., 28, 219 бөл., 220, тел.: 272-13-19, 272-13-18, http://nauka-nanrk.kz. social-human.kz

(C) Қазақстан Республикасының Ұлттық ғылым академиясы, 2018

Типографияның мекенжайы: «Аруна» ЖК, Алматы қ., Муратбаева көш., 75. 
Главный редакто $p$

Почетный член НАН РК

T.O. Балыкбаев

Р е дак ци онн а я коллег и я:

докт. экон. Н., проф., академик НАН РК У.Б. Баймуратов; докт. ист. н., проф., академик НАН РК К.М. Байпаков; докт. филос. Н., проф., академик НАН РК Г.Е. Есим; докт. фил. Н., проф., академик НАН РК С.С. Кирабаев; докт. экон. Н., проф., академик НАН РК А.К. Кошанов; докт. экон. Н., проф., академик НАН РК К.Н. Нарибаев (заместитель главного редактора); докт. филос. н., проф., академик НАН РК А.Н. Нысанбаев; докт. юр. Н., проф., академик НАН РК С.Н. Сабикенов; докт. юр. н., проф., академик НАН РК М.К. Сулейменов; докт. экон. Н., проф., академик НАН РК С.С. Сатубалдин; докт. ист. н., проф., академик НАН РК Х.М. Абжанов; докт. ист. н., проф., чл.-корр. НАН РК М.Х. Абусеитова; докт. ист. н., проф., академик НАН РК Б.А. Байтанаев; докт. фил. н., проф., чл.-корр. НАН РК Б.А. Жакып; докт. фиолол. н., проф., академик НАН РК У.К. Калижанов; докт. фил. н., проф., академик НАН РК Д. Камзабекулы; докт. ист. н., проф., академик НАН РК Д.П. Кожамжарова; докт. ист. н., проф., академик НАН РК М.К. Койгельдиев; докт. филол. н., проф., чл.-корр. НАН РК Ш. Курманбайулы; докт. ист. н., проф., чл.корр. НАН РК Ж.К. Таймаганбетов; докт. социол. н., проф., чл.-корр. НАН РК З.К. Шаукенова; д. филол. н., проф., чл.-корр. НАН РК А. Дербисали; доктор политических наук, проф., Бижанов А.К.; доктор ист. наук, проф., Кабульдинов 3.Е.; доктор филол. н., проф., член-корр. НАН РК Қажыбек Е.3.

Р е дак ци онны й с ов е т

академик НАН Республики Молдова Г. Белостечник (Молдова); академик НАН Азербайджанской Республики Н. Велиханлы (Азербайджан); академик НАН Республики Таджикистан Т.Н. Назаров (Таджикистан); академик НАН Республики Молдова А. Рошка (Молдова); академик НАН Республики Молдова Г. Руснак (Молдова); чл.-корр. НАН Азербайджанской Республики Ш. Мурадов (Азербайджан), член-корр. НАН Азербайджанской Республики 3.Сафарова (Азербайджан); д. э. н., проф. В.Н. Василенко (Украина); д.ю.н., проф. В.А. Устименко (Украина)

Известия Национальной академии наук Республики Казахстан. Серия общественных и гуманитарных наук. ISSN 2224-5294

Собственник: РОО «Национальная академия наук Республики Казахстан» (г. Алматы)

Свидетельство о постановке на учет периодического печатного издания в Комитете информации и архивов

Министерства культуры и информации Республики Казахстан № 10894-Ж, выданное 30.04.2010 г.

Периодичность 6 раз в год

Тираж: 500 экземпляров

Адрес редакции: 050010, г. Алматы, ул. Шевченко, 28, ком. 219, 220, тел. 272-13-19, 272-13-18, www:nauka-nanrk.kz / social-human.kz

(C) Национальная академия наук Республики Казахстан, 2018 г.

Адрес типографии: ИП «Аруна», г. Алматы, ул. Муратбаева, 75

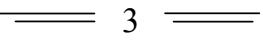


Chief Editor

\section{Honorary member of NAS RK \\ Balykbayev T.O}

Editorial board:

Doctor of economics, prof, academician of NAS RK Baimuratov U.B.; doctor of history, prof, academician of NAS RK Baipakov K.M.; doctor of philosophy, prof, academician of NAS RK Esim G.E.; doctor of philology, prof, academician of NAS RK Kirabayev S.S.; doctor of economics, prof, academician of NAS RK Koshanov A.K.; doctor of economics, prof, academician of NAS RK Naribayev K.N. (deputy editor-in-chief); doctor of philosophy, prof, academician of NAS RK Nyssanbayev A.N.; doctor of law, prof, academician of NAS RK Sabikenov S.N.; doctor of law, prof, academician of NAS RK Suleymenov M.K.; doctor of economy, prof, academician of NAS RK Satybaldin S.S.; doctor of history, prof, academician of NAS RK Abzhanov H.M; doctor of history, prof, corresponding member of NAS RK Abuseitova M.H.; doctor of history, prof, academician of NAS RK Baitanaev B.A.; doctor of philology, prof, corresponding member of NAS RK Zhakyp B.A.; doctor of philology, prof, academician of NAS RK Kalizhanov U.K.; doctor of philology, prof, academician of NAS RK Hamzabekuly D.; doctor of history, prof, academician of NAS RK Kozhamzharova D.P.; doctor of history, prof, academician of NAS RK Koigeldiev M.K.; doctor of philology, prof, corresponding member of NAS RK Kurmanbaiuly Sh.; doctor of history, prof, academician of NAS RK Taimaganbetov J.K.; doctor of sociology, prof, corresponding member of NAS RK Shaukenova Z.K.; doctor of philology, prof, corresponding member of NAS RK Derbisali A.; doctor of political science, prof Bizhanov A.K; doctor of History, prof Kabuldinov Z.E.; doctor of philology, prof, corresponding member of NAS RK Kazhybek E.Z.

\section{Editorial staff:}

Academician NAS Republic of Moldova Belostechnik.G (Moldova); Academician NAS Republic of Azerbaijan Velikhanli N. (Azerbaijan); Academician NAS Republic of Tajikistan Nazarov T.N. (Tajikistan); Academician NAS Republic of Moldova Roshka A. (Moldova) Academician NAS Republic of Moldova Rusnak G. (Moldova); Corresponding member of the NAS Republic of Azerbaijan Muradov Sh. (Azerbaijan); Corresponding member of the NAS Republic of Azerbaijan Safarova Z. (Azerbaijan); Associate professor of Economics Vasilenko V.N. (Ukraine), Associate professor of Law Ustimenko V.A. (Ukraine)

News of the National Academy of Sciences of the Republic of Kazakhstan. Series of Social and Humanities. ISSN 2224-5294

Owner: RPA "National Academy of Sciences of the Republic of Kazakhstan" (Almaty)

The certificate of registration of a periodic printed publication in the Committee of information and archives of the Ministry of culture and information of the Republic of Kazakhstan N 10894-Ж, issued 30.04.2010

Periodicity: 6 times a year

Circulation: 500 copies

Editorial address: 28, Shevchenko str., of. 219, 220, Almaty, 050010, tel. 272-13-19, 272-13-18, www:nauka-nanrk.kz / social-human.kz

(C) National Academy of Sciences of the Republic of Kazakhstan, 2018

Address of printing house: ST "Aruna", 75, Muratbayev str, Almaty 
N E W S

OF THE NATIONAL ACADEMY OF SCIENCES OF THE REPUBLIC OF KAZAKHSTAN

SERIES OF SOCIAL AND HUMAN SCIENCES

ISSN 2224-5294

https://doi.org/10.32014/2018.2224-5294.21

Volume 5, Number 321 (2018), 119 - 125

\author{
V. F. Stukach ${ }^{1}$, A.S. Baydalinova ${ }^{2}$, B.A. Sandybayeva ${ }^{3}$ \\ 'd.e.s., professor, the Omsk state agricultural university after P.A. Stolypin, Omsk, Russian Federation; \\ ${ }^{2}$ Doctoral candidate of PhD, JSC Financial Academy, Astana, Kazakhstan; \\ ${ }^{3}$ Master, JSC Kazakh University of Economics, Finance and International Trade, Astana, Kazakhstan \\ E-mail:vic.econ@mail.ru; E-mail: aynur.sultanovna@mail.ru; E-mail: balzhan_s@list.ru
}

\title{
KAZAKHSTANI FINANCIAL SAFETY
}

\begin{abstract}
Ensuring financial safety of the state is an important task for many countries. This task becomes a priority before the danger of a financial crisis. Especially it is true when the state is in the zone of the financial crisis, since such a situation a priori means a loss of financial safety to some extent.

Keywords: financial safety, public debt, financial crisis, economic security, external debt, budget deficit, gross domestic product.
\end{abstract}

Methods of a research. In the methodological basis of the study lies the system of common, separate and special methodological principles, approaches and methods of scientific cognition, applicable either separately or in combination with each other. In particular, there have been used such methods as dialectical, historical, comparative analysis, simulation, statistical and systematic-structural, action and situational approaches to the study of the processes and phenomena.

Methodological basis of the work is an integrated approach that is applied by the author for the study and analysis of financial security as an essential component of national economic security. The methods are implemented of systematic analysis of the financial security formation processes, historical and economic analysis. In order to achieve the objective results of the study these methods were applied comprehensively.

Introduction. Financial safety of the state is an important component of system of economic security at the macrolevel.

Security of interests of the state as financial sphere is understood under the financial safety of the state or such condition of the budgetary, tax and monetary and credit systems which guarantees ability of the state effectively to form, preserve from excessive depreciation and is rational to use financial resources of the country for ensuring social and economic development and service of financial obligations [1]. The level of development of the real sector of economy, production, and all other elements and types of safety depends on a condition of financial safety $[2,3,4]$.

The financial component is a fundamental and fundamental basis in all spheres of activity of the state in each country. Any civilized state in the atmosphere of the undivided international competition, advocates the interests, from the national, finishing financially - economic. Functions of the state can be considered as really effective only in this or that country when they provide comfortable and safe accommodation of the person. It is impossible to keep integrity and unity of a financial system without ensuring financial safety of the state, to successfully overcome internal and external threats. The most important role of finance in economic security of the state consists in maintenance of ability to carry out independent financially - economic policy according to the national interests. Generally money and financial system are a condition of wellbeing and an opportunity to realize aspirations both the states in general and separately taken person.

Financial safety is considered from various points of view. In general, the solution of all matters of state influences on economic safety of the state. It is impossible to rely on accidents or any certain basic 
knowledge which concern, for example, foreign countries in this question. As a rule, each separately taken state has, original, a line of development. It concerns, both specific features in the social sphere and political realities.

Financial safety consists of complementary components without impossible to present any development leading to progress. It is required to consider all set of fields of activity in which there takes place development and a favorable tide of life of everyone by their consideration. It is possible to distinguish from them:

- resource approach provides security of all economic needs of subjects of managing, considering all levels of the monetary relations. It concerns to all areas, since the small organizations, finishing with large sectors of economy of the state; all financial resources intended for satisfaction of requirements and implementation of obligations have to be considered;

- consideration in statistics indicators which characterizes a certain condition of monetary and credit, currency, bank, budgetary, tax, investment, customs and tariff and share systems. All the list gives stability and provides resistance to internal and external influences and also gives the chance for prevention of external economic expansion, guarantees effective functioning of a national financial system and economic growth;

- standardly - legal regulation provides development of certain stable conditions in order that the financial system could function in a favorable ratio, that is, in - the first, there was no opportunity to direct financial flows to spheres of their use loose by legislative regulations and, secondly, the possibility of abuse of financial resources would be lowered to a minimum.

The most important is a maintaining financial sovereignty of the country, independence of external influence. As shows the analysis it is almost impossible to achieve "absolute" financial independence in the conditions of globalization, at the same time. In spite of the fact that financial safety goes beyond national interests, the role of the government consists in development of the strategy focused on sovereignty. It assumes need to analyze and consider the current and probable situation in the world foreign exchange markets and the capital markets. In fact, financial safety represents rather difficult multilevel system therefore for the good of the multimillion population it is so important to understand all subtleties of financial requirements not only inside, but also outside the country [5].

Results and discussion. Development of a financial system has unstable character and is caused by existence of a number of key problems in the Republic of Kazakhstan, many of them have long character that is also confirmed by intercountry estimates of the leading international organizations. Signs of stagnation of the financial market for the last years are caused by the internal reasons, and restrictions from the real sector, in particular:

1) priorities of crediting by banks reflect disproportions in structure of the economic growth which is based on consumer demand, but not on investments;

2) a limited set of the services rendered to the large enterprises and inability of banks to accumulate independently essential volume of the resources necessary for financing of large-scale investment projects define dependence of financing of the priority directions of development of economy, including small and average business, in many respects from the resources allocated by the state;

3) "distortion" towards retail funding of a banking system at the actual lack of the market of redistribution of liquidity and backwardness of mechanisms of refinancing does system subject to risks of "change of moods" of investors;

4) the high volume of idle loans reduces possibilities of the banking sector to react flexibly to changes of the macroeconomic environment, a situation in the separate markets;

5) discrepancy of structure of assets and liabilities of a banking system by types of currencies as creditors of banks increase preferences to foreign currency, and borrowers - to national currency;

6) lack of internal points of growth of other segments, in particular insurance when development is provided thanks to obligatory types of insurance or the accompanying insurance as cross-sales when crediting by banks, retirement annuities due to transfers of pension savings from the accumulative pension funds in insurance companies;

7) the system risk connected with high unprofitability of separate types of insurance as a result of legislative restriction of the size of insurance tariffs and deregulation of the state functions with transfer to their commercial insurance companies without due selection of risks; 
8) the low potential of non-bank institutional investors in the market of private investments when possibilities of insurance companies are limited to transfer of essential volume of insurance premiums to nonresident overcautious persons of the Republic of Kazakhstan, and in management of pension money during creation of the Uniform accumulative pension fund (further - UAPF) comes a question of ensuring safety of funds due to decrease in risks of investment to the forefront;

9) deficiency of the offer and unattractiveness of instruments of securities market concerning deposits of banks and the real estate market for retail investors;

10) as a result, lack of alternativeness to the market of banking services from securities market;

11) emergence and growth of the alternative (nonconventional) organizations providing financial services, and change of behavior of consumers concerning where and as they get financial services and products can serve easing of competitiveness of the banking sector of the Republic of Kazakhstan;

12) noncompetitiveness of Regional financial center of Almaty (further - RFCA) in comparison with world financial centers as a result of the main problems of securities market of the country inherent at this stage of his development and also the problems having system character (infrastructure, economic, investment, business, social, transport, ecological) [6].

As well as economic security financial safety of the state is estimated on a number of indicators indicators of safety of a financial system of the state (table 1).

Table 1-Indicators of financial safety of the state

\begin{tabular}{|c|c|c|}
\hline Stability indicator & Parameter, stability indicator & Threshold values \\
\hline $\begin{array}{l}\text { 1. Shortage level of the budget } \\
\text { (the federal, consolidated state) }\end{array}$ & $\begin{array}{l}\text { The excess of expenses of the budget over } \\
\text { income expressed as a percentage to budget } \\
\text { revenues }\end{array}$ & $\begin{array}{l}\text { Up to } 20 \% \text { within one year } \\
\text { Up to } 10 \% \text { within several years }\end{array}$ \\
\hline 2. Price stability & $\begin{array}{l}\text { Annual rate of inflation (increase in prices for } \\
\text { goods and services) as a percentage }\end{array}$ & $\begin{array}{l}\text { No more than } 50 \% \text { within a year } \\
\text { No more than } 25 \% \text { within several years } \\
\text { in a row } \\
\text { No more than } 10 \% \text { for a number of years }\end{array}$ \\
\hline $\begin{array}{l}\text { 3. Gold and exchange stock of } \\
\text { the country }\end{array}$ & $\begin{array}{l}\text { Existence of a gold and foreign exchange } \\
\text { reserve capable to suppress the splashes in a } \\
\text { rate of foreign currencies unforeseen - the } \\
\text { public expenditures, requirements for return of } \\
\text { debts. The size of a reserve is measured } \\
\text { percentage of the state budget and GDP }\end{array}$ & $\begin{array}{l}\text { It isn't lower than } 40 \% \text { of consolidated } \\
\text { state budget } \\
\text { It isn't lower than } 20 \% \text { of gross domestic } \\
\text { product } \\
\text { It isn't lower than } 25 \% \text { of money supply } \\
\text { which is in circulation }\end{array}$ \\
\hline $\begin{array}{l}\text { 4. External debt of the country } \\
\text { (state and corporate) }\end{array}$ & $\begin{array}{l}\text { Real ability to repay a debt in time, to re- } \\
\text { structure the debt, to compensate a debt at the } \\
\text { expense of the available assets or loans. It is } \\
\text { measured by debt size as a percentage to GDP, } \\
\text { the budget or to a liquid part of a national } \\
\text { wealth }\end{array}$ & $\begin{array}{l}\text { No more than } 50 \% \text { of GDP at duration } \\
\text { of the period of return of a debt not less } \\
\text { than } 10 \text { years } \\
\text { No more than } 20 \% \text { of load of the budget } \\
\text { within one year } \\
\text { No more than } 5 \% \text { of a national wealth }\end{array}$ \\
\hline 5. Internal public debt & $\begin{array}{l}\text { Real ability to repay a debt, to restructure it, to } \\
\text { cover with issue of the guaranteed state } \\
\text { securities or to compensate a debt at the } \\
\text { expense of elements of a national wealth. gold } \\
\text { and exchange stock }\end{array}$ & $\begin{array}{l}\text { No more than } 75 \% \text { of GDP at duration } \\
\text { of the period of return of a debt not less } \\
\text { than } 10 \text { years } \\
\text { No more than } 20 \% \text { of load of the budget } \\
\text { within one year }\end{array}$ \\
\hline $\begin{array}{l}\text { 6. Deficiency of the balance of } \\
\text { payments }\end{array}$ & $\begin{array}{l}\text { Excess of import over export, external } \\
\text { payments over external receipts, as a } \\
\text { percentage to balance size }\end{array}$ & $\begin{array}{l}\text { No more than } 50 \% \text { within one year } \\
\text { No more than } 20 \% \text { within several years }\end{array}$ \\
\hline
\end{tabular}

Thereby the high level of financial danger to the country is created not only by deviations of parameters of functioning of a financial system, considerable in size, from calculated, standard values in the form of local "splashes" [8]. For example, it is known, that even large splashes or failures of exchange rates, rates of securities manage to be extinguished if they don't gain long character from experience. At the same time very long action of threats, not so large in size, is capable to undermine safety in connection with action of effect of "accumulation".

We will analyse indicators of financial safety according to National bank of Kazakhstan (table 2) [9]. 
Table 2 - Indicators of financial safety of Kazakhstan

\begin{tabular}{|l|l|l|l|l|l|l|l|l|l|l|l|}
\hline Indicator & 2007 & 2008 & 2009 & 2010 & 2011 & 2012 & 2013 & 2014 & 2015 & 2016 & 2017 \\
\hline $\begin{array}{l}\text { Shortage level } \\
\text { of the budget }\end{array}$ & $-7,5$ & $-8,3$ & $-14,1$ & $-12,3$ & $-10,6$ & $-15,3$ & $-11,0$ & $-14,8$ & $-12,0$ & $-7,9$ & $-12,6$ \\
\hline Price stability & 118,8 & 109,5 & 106,2 & 107,8 & 107,4 & 106,0 & 104,8 & 107,4 & 113,6 & 108,5 & 107,1 \\
\hline $\begin{array}{l}\text { Gold and } \\
\text { exchange stock } \\
\text { of the country }\end{array}$ & 16,5 & 14,5 & 20,1 & 19,1 & 15,2 & 13,6 & 10,4 & 13,1 & 15,1 & 21,5 & $* * *$ \\
\hline $\begin{array}{l}\text { External debt of } \\
\text { the country } \\
\text { (state and } \\
\text { corporate) }\end{array}$ & 92,4 & 80,9 & 97,9 & 79,9 & 65,1 & 65,8 & 63,4 & 71,2 & 83,2 & 119,2 & 105,9 \\
\hline $\begin{array}{l}\text { Internal public } \\
\text { debt }\end{array}$ & 4,1 & 5,1 & 7,5 & 7,6 & 7,3 & 9,2 & 8,1 & 10,6 & 6,9 & 9,3 & 10,7 \\
\hline $\begin{array}{l}\text { Deficiency of } \\
\text { the balance of } \\
\text { payments }\end{array}$ & $-55,0$ & 18,6 & $-27,5$ & 4,9 & 22,7 & 2,8 & 3,7 & 16,9 & $-40,5$ & $-96,5$ & $-30,7$ \\
\hline
\end{tabular}

As shown from the table 2, the majority of indicators of financial safety of Kazakhstan are brought closer to critical value or even exceed them.

The shortage level of the budget, as well as the rate of inflation during the analyzed period is in limits of threshold value up to $10 \%$ within 10 years. Level of gold and exchange stocks of the country in relation to GDP from 2007 to 2015 is lower than $20 \%$, in 2016 he has reached $21 \%$ that corresponds to extreme value. The indicator of an external debt of Kazakhstan which exceeds GDP of the country for 3,4\% in 2017 is alarming. As and for all analyzed period from 2007 to 2017 the indicator of an external debt was in the principle above the maximum permissible level of 50\% of GDP of the state. Level of an internal debt and deficiency of the balance of payments meets limit rates for the studied period.

The external debt of public sector in expanded definition includes:

- external public debt,

- an external debt of banks and organizations in which state bodies and monetary and credit regulation directly or it is mediated own more, than $50 \%$ of participation in the capital or control them a different way (the organization controlled by the state);

- the external debt provided with guarantees or guarantees of the state.

We will analyse in more detail statistics of an external debt of RK for 2007-2017.

Table 3 - Dynamics of an external debt of RK

\begin{tabular}{|c|c|c|c|c|c|c|c|c|c|c|c|}
\hline Name of an indicator & 2007 & 2008 & 2009 & 2010 & 2011 & 2012 & 2013 & 2014 & 2015 & 2016 & 2017 \\
\hline 1 & 2 & 3 & 4 & 5 & 6 & 7 & 8 & 9 & 10 & 11 & 12 \\
\hline \multicolumn{12}{|c|}{ Absolute parameters (mln. dollars of the USA) } \\
\hline $\begin{array}{l}\text { 1. An external debt } \\
\text { (assessment for the end of } \\
\text { the period) }\end{array}$ & $\begin{array}{l}96 \\
893,0\end{array}$ & $\begin{array}{l}107 \\
933,4\end{array}$ & $\begin{array}{l}112 \\
866,9\end{array}$ & $\begin{array}{l}118 \\
222,8\end{array}$ & $\begin{array}{l}125 \\
320,8\end{array}$ & $\begin{array}{l}136 \\
918,2\end{array}$ & $\begin{array}{l}150 \\
032,9\end{array}$ & $\begin{array}{l}157 \\
561,5\end{array}$ & $\begin{array}{l}153 \\
422,2\end{array}$ & $\begin{array}{l}163 \\
631,7\end{array}$ & $\begin{array}{l}167 \\
484,7\end{array}$ \\
\hline $\begin{array}{l}\text { including, intercompany } \\
\text { debt }\end{array}$ & $\begin{array}{l}30 \\
080,6 \\
\end{array}$ & $\begin{array}{l}40 \\
198,8 \\
\end{array}$ & $\begin{array}{l}49 \\
632,0 \\
\end{array}$ & $\begin{array}{l}52 \\
274,7 \\
\end{array}$ & $\begin{array}{l}62 \\
576,2 \\
\end{array}$ & $\begin{array}{l}67 \\
608,3 \\
\end{array}$ & $\begin{array}{l}74 \\
179,5 \\
\end{array}$ & $\begin{array}{l}79 \\
581,8 \\
\end{array}$ & $\begin{array}{l}96 \\
679,1 \\
\end{array}$ & $\begin{array}{l}104 \\
767,5 \\
\end{array}$ & $\begin{array}{ll}104 \\
463,0\end{array}$ \\
\hline $\begin{array}{l}\text { Specific weight in structure } \\
\text { of an external debt of } \\
\text { intercompany debt }\end{array}$ & 31,0 & 37,2 & 44,0 & 44,2 & 49,9 & 49,4 & 49,4 & 50,5 & 63,0 & 64,0 & 62,4 \\
\hline $\begin{array}{l}\text { 2. External debt, only } \\
\text { intercompany debt } \\
\text { (assessment for the end of } \\
\text { the period) }\end{array}$ & $\begin{array}{l}66 \\
812,4\end{array}$ & $\begin{array}{l}67 \\
734,6\end{array}$ & $\begin{array}{l}63 \\
234,9\end{array}$ & $\begin{array}{l}65 \\
948,0\end{array}$ & $\begin{array}{l}62 \\
744,6\end{array}$ & $\begin{array}{l}69 \\
310,0\end{array}$ & $\begin{array}{l}75 \\
853,4\end{array}$ & $\begin{array}{l}77 \\
979,7\end{array}$ & $\begin{array}{l}56 \\
743,1\end{array}$ & $\begin{array}{l}58 \\
864,2\end{array}$ & $\begin{array}{l}63 \\
021,6\end{array}$ \\
\hline $\begin{array}{l}\text { 3. Payments on repayment } \\
\text { and service of a long-term } \\
\text { external debt (incl. } \\
\text { intercompany debt) }\end{array}$ & $\begin{array}{l}28 \\
843,6\end{array}$ & $\begin{array}{l}34 \\
096,9\end{array}$ & $\begin{array}{l}38 \\
970,5\end{array}$ & $\begin{array}{l}25 \\
397,9\end{array}$ & $\begin{array}{l}29 \\
622,6\end{array}$ & $\begin{array}{l}31 \\
951,5\end{array}$ & $\begin{array}{l}31 \\
869,5\end{array}$ & $\begin{array}{l}31 \\
775,9\end{array}$ & $\begin{array}{l}38 \\
203,6\end{array}$ & $\begin{array}{l}31 \\
328,9\end{array}$ & $\begin{array}{l}37 \\
117,5\end{array}$ \\
\hline
\end{tabular}




\begin{tabular}{|c|c|c|c|c|c|c|c|c|c|c|c|}
\hline & & & & & & & & \multicolumn{4}{|c|}{ Продолжение таблииы 3} \\
\hline 1 & 2 & 3 & 4 & 5 & 6 & 7 & 8 & 9 & 10 & 11 & 12 \\
\hline $\begin{array}{l}\text { 4. Payments on repayment } \\
\text { and service of a long-term } \\
\text { external debt (only } \\
\text { intercompany debt) }\end{array}$ & $\begin{array}{l}20 \\
644,8\end{array}$ & $\begin{array}{l}25 \\
311,2\end{array}$ & $\begin{array}{l}31 \\
030,5\end{array}$ & $\begin{array}{l}15 \\
637,8\end{array}$ & $\begin{array}{l}16 \\
875,1\end{array}$ & $\begin{array}{l}18 \\
902,4\end{array}$ & $\begin{array}{l}19 \\
317,5\end{array}$ & $\begin{array}{l}17 \\
885,7\end{array}$ & $\begin{array}{l}24 \\
643,3\end{array}$ & $\begin{array}{l}14 \\
342,6\end{array}$ & $\begin{array}{l}14 \\
110,4\end{array}$ \\
\hline \multicolumn{12}{|l|}{ Relative parameters } \\
\hline $\begin{array}{l}\text { 1. External debt per capita } \\
\text { (US dollar, claim. } \\
\text { intercompany debt) } *\end{array}$ & $\begin{array}{l}4 \\
292,3\end{array}$ & $\begin{array}{l}4 \\
238,1\end{array}$ & $\begin{array}{l}3 \\
902,6\end{array}$ & $\begin{array}{l}4 \\
011,3\end{array}$ & $\begin{array}{l}3 \\
763,0\end{array}$ & $\begin{array}{l}4 \\
098,7\end{array}$ & $\begin{array}{l}4 \\
420,1\end{array}$ & $\begin{array}{l}4 \\
477,5\end{array}$ & $\begin{array}{l}3 \\
211,3\end{array}$ & $\begin{array}{l}3 \\
285,2\end{array}$ & $\begin{array}{l}3 \\
470,9\end{array}$ \\
\hline $\begin{array}{l}\text { 2. The relation of an } \\
\text { external debt to GDP (\%, } \\
\text { incl. intercompany debt) }\end{array}$ & 92,4 & 80,9 & 97,9 & 79,9 & 65,1 & 65,8 & 63,4 & 71,2 & 83,2 & 119,2 & 105,9 \\
\hline $\begin{array}{l}\text { 3. Relation of an external } \\
\text { debt to GDP }(\% \text {, only } \\
\text { intercompany debt })\end{array}$ & 63,7 & 50,8 & 54,8 & 44,5 & 32,6 & 33,3 & 32,1 & 35,2 & 30,8 & 42,9 & 39,8 \\
\hline $\begin{array}{l}\text { 4. The relation of an } \\
\text { external debt to EGS (\%, } \\
\text { incl. intercompany debt) }\end{array}$ & 187,1 & 141,5 & 235,0 & 180,5 & 140,0 & 149,2 & 164,9 & 181,3 & 289,5 & 375,6 & 300,5 \\
\hline $\begin{array}{l}\text { 5. Relation of an external } \\
\text { debt to EGS (\%, only } \\
\text { intercompany debt) }\end{array}$ & 129,0 & 88,8 & 131,7 & 100,7 & 70,1 & 75,5 & 83,4 & 89,7 & 107,1 & 135,1 & 113,1 \\
\hline $\begin{array}{l}\text { 6. The relation of payments } \\
\text { on repayment and service of } \\
\text { a long-term external debt to } \\
\text { EGS (\%, incl. intercompany } \\
\text { debt) }\end{array}$ & 55,7 & 44,7 & 81,1 & 38,8 & 33,1 & 34,8 & 35,0 & 36,6 & 72,1 & 71,9 & 66,6 \\
\hline $\begin{array}{l}\text { 7. The relation of payments } \\
\text { on repayment and service of } \\
\text { a long-term external debt to } \\
\text { EGS (\%, only intercompany } \\
\text { debt) }\end{array}$ & 39,9 & 33,2 & 64,6 & 23,9 & 18,8 & 20,6 & 21,2 & 20,6 & 46,5 & 32,9 & 25,3 \\
\hline $\begin{array}{l}\text { 8. Relation of payments of } \\
\text { remuneration to EGS }(\%)\end{array}$ & 10,9 & 8,1 & 11,0 & 7,2 & 5,3 & 5,6 & 5,5 & 5,8 & 9,9 & 12,8 & 11,6 \\
\hline $\begin{array}{l}\text { 9. Relation of reserve assets } \\
\text { of National Bank of } \\
\text { Kazakhstan to a short-term } \\
\text { external debt }(\%)\end{array}$ & 152,9 & 209,2 & 330,3 & 318,6 & 372,4 & 311,1 & 261,0 & 300,7 & 445,2 & 449,8 & 412,3 \\
\hline $\begin{array}{l}\text { 10. The relation of reserve } \\
\text { assets of National Bank of } \\
\text { Kazakhstan to a short-term } \\
\text { external debt on the term } \\
\text { which has remained before } \\
\text { repayment (Rule Gvidotti) } \\
(\%)\end{array}$ & 59,7 & 65,8 & 109,4 & 116,5 & 131,8 & 104,7 & 105,0 & 107,1 & 126,0 & 122,1 & 114,4 \\
\hline $\begin{array}{l}\text { 11. The relation of reserve } \\
\text { assets of National Bank of } \\
\text { Kazakhstan and foreign } \\
\text { assets of National RK Fund } \\
\text { to a short-term external debt } \\
\text { for the term which has } \\
\text { remained before repayment } \\
(\%)\end{array}$ & $*$ & $*$ & $*$ & $*$ & $*$ & $*$ & 405,8 & 375,5 & 412,6 & 375,4 & 331,3 \\
\hline
\end{tabular}

The note - is made by the author

Apparently from data of table 3, absolute parameters of an external debt tend growth from year to year, and by the end of 2017 the volume of an external debt is 167484,7 million US dollars. It should be noted changes in structure of an external debt, so, for example till 2014 the largest specific weight occupied a public debt, and since 2015 in structure intercompany debt already prevails.

The external debt per capita in 2017 has made 3470,9 US dollars. Change of this indicator since 2007 - 4292,3 to - 3470,9 US dollars is connected with increase in population. 
It should be noted that, growth of volumes of the gross domestic product (GDP) and export of goods and services (EGS) promotes improvement of all relative parameters of an external debt for example: the relation of an external debt to GDP has made $105,49 \%$ in comparison with 2016 of $-119,2 \%$, and the relation of an external debt to EGS are $300,5 \%$ in comparison with $375,6 \%$.

Thus, considering growth of volumes of GDP and export of goods and services in 12 months preceding reporting date, the relative parameters of an external debt tied to these indicators have improved in comparison with 2016.

The net external debt of the Republic of Kazakhstan as of October 1, 2017 has made 43,9 bln. dollars or $28,3 \%$ to GDP, having increased for the 3rd quarter 2017 by 2,8 bln. dollars or $6,7 \%$, generally owing to reduction of assets of National fund in instruments of the monetary market.

At the same time the state and financial sectors act as clean creditors in relation to the rest of the world (a net external debt (-) 56,8 and (-) 14,3 bln. dollars, respectively) whereas the corporate nonfinancial sector (including intercompany debt) is a clean borrower (a net external debt of 115,1 bln. dollars).

In structure of an external debt of Kazakhstan on a repayment period of 95,5\% it falls on long-term (over 1 year) an external debt that, on the one hand, minimizes risks of liquidity, and with another strengthens influence on repayment and debt servicing of change of the general market conditions.

In structure of an external debt of Kazakhstan by types of financial instruments the credits and loans attracted from nonresidents $(79,1 \%)$ and debt securities on hands at nonresidents $(12,8 \%)$ prevail.

According to the Report of global competitiveness 2017 - 2018 of the World Economic Forum Kazakhstan on an indicator "The credit rating of the country" was downgraded on the 62nd place (the 54th place in 2015) [10].

Conclusion. So, it should be noted not compliance of the reached levels of indicators financial safety to the set parameters, summing up the result of the analysis of financial safety of Kazakhstan. And some indicators demonstrate undermining safety of the state in the financial sphere as have "accumulative character".

One of mechanisms of management of the state and guaranteed by the state debt according to the Budgetary code, a debt according to guarantees of the state and risks is annual assessment of a state and the forecast for the forthcoming planning period of the state and guaranteed by the state loan, is long and long according to guarantees of the state. In 2017 changes in a part of weakening of the budgetary rules concerning policy of management of a public debt are made to the Concept of new budgetary policy. The threshold value by 2020 on a public debt has been increased from $13,9 \%$ to $27 \%$ to GDP, threshold value on a government debt - from $13,7 \%$ to $25 \%$ to GDP.

From 2015 for 2017 the Ministries of Finance, national economy and National Bank such annual assessment was carried out only within implementation of strategic plans without development of the complex conclusion and the general conclusions.

For ensuring economic security of the country carrying out the balanced debt policy of the state with establishment of specific goals on development of domestic market of securities is recommended.

In the long term for ensuring effective protection against debt threat of national security of Kazakhstan of most of economists $[11,12]$ the following is offered:

- studying of an opportunity and expediency of establishment of threshold values of the relation of an external debt to GDP in the separate directions (sectors of economy) and other possible measures of restriction of external loan taking into account the prospects of development of certain sectors and branches of economy of the republic;

- control of target orientation of the borrowed funds from a position of effective achievement of goals of social and economic development of the country;

- creation of a full-fledged risk management system in the national companies and holdings for minimization of system risks of a debt and timely identification of threats of debt stability;

- improvement of mechanisms of control from the state of a condition of a debt of the quasi-public sector, with the subsequent restriction of volumes and introduction of the ban for implementation of external loans by certain subjects of the quasi-public sector;

- diversification of sources of loans and currency structure of an external debt;

- entering of corresponding changes and additions into the current legislation for management of an external debt, further improvement of legal base of rather external debt (on the basis of real economic calculations and forecasts);

- optimization and rationalization of payments for service and repayment of an external debt due to improvement of its structure and in general increase in efficiency of formation of policy of management of a public debt;

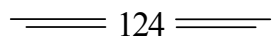


- creation of special institutional structures which will conduct a research of favorable opportunities for attraction of the international credits, the analysis of efficiency of use of the borrowed means and the credited projects, researches in the area an obsluzhivakniya of an external debt.

\title{
REFERENCES
}

[1] Horosheva A. S. Conditions of ensuring financial safety of the state/A. S. Horosheva//Finance, account, banks. No. 14. 2008. Page $90-96$

[2] Tkachenko V.G. About features of financial safety of Ukraine in the conditions of market transformational processes / V.G. Tkachenko//Mezhnarodny the naukovo-virobnichy magazine "Ekonomika of Agrarian and Industrial Complex". No. 6. 2009. Page 8-14.

[3] Petrushchak B. (2009)The negative aspects of globalization's influence on financial system. Bohdan Petrushchak. http://mpra.ub.uni-muenchen.de/30019/

[4] Soros G. Das Ende der Finanzmärkte und deren Zukunft: die heutige Finanzkrise und was sie bedeutet. München. FinanzBuch Verlag GmbH. 2008. S.174.

[5] A role of finance in economic security of the state. Yu.A. Kalimullina, cadet of UYuI Ministry of Internal Affairs of the Russian Federation R.R. Yarullin, Dr.Econ.Sci., professor of the Ufa branch of Financial University under the Government of the Russian Federation. International scientific magazine "Innovatsionnaya Nauka" No. 7-8/2016 issn 2410-6070.

[6] The resolution of the government of the Republic of Kazakhstan of August 27, 2014 No. 954 "About the approval of the Concept of development of the financial sector of the Republic of Kazakhstan till 2030".

[7] Karanina, E. V. financial safety (at the level of the state, the region, the organization, the personality): monograph / E.V. Karanina. Kirov: ViyatSU, 2016.-240 with. 2016.

[8] Stigliz J Globalization and growth in emerging markets // Journal of Policy Modeling. 2004. №26. P.465-484.

[9] Website of National bank of the Republic of Kazakhstan. Annual reports of NBK for 2007-2017. Electronic resource. http://nationalbank.kz. Date of the address of 1.04.2018.

[10] The report of the World Economic Forum on global competitiveness for 2017-2018.

[11] L. Dauletbayeva, G.M. Kalkabayeva. Current state and problems of management of an external debt of the Republic of Kazakhstan. Messenger KarSU No. 03 (71) magazine. Karaganda: Publishing house KarSU, 2013. 160 pages - ISSN $0142-0843$.

[12] S.M. Omirbayev, S.Zh. Intykbayeva, A.A. Adambekova, Parmanova R.S. State budget: Textbook / Omirbayev S.M., Intykbayeva S.Zh., Adambekova A.A. Parmanova R.S. Almaty: RPIK LLP, 632 page 2011.

\section{В. Ф. Стукач ${ }^{1}$, А. С. Байдалинова ${ }^{2}$, Б. А. Сандыбаева ${ }^{3}$}

${ }^{1}$ Омский государственный сельскохозяйственный университет имени П.А. Столыпина, Омск, Российская Федерация;

${ }^{2}$ Финансовая академия, Астана, Казахстан;

${ }^{3} \mathrm{AO}$ «Казахстанский университет экономики, финансов и международной торговли», Астана, Казахстан

\section{КАЗАХСТАНСКАЯ ФИНАНСОВАЯ БЕЗОПАСНОСТЬ}

Аннотация. Обеспечение финансовой безопасности государства является важной задачей для многих стран. Эта задача становится приоритетной перед опасностью финансового кризиса. Особенно это верно, когда государство находится в зоне финансового кризиса, поскольку такая ситуация априори означает некоторую потерю финансовой безопасности.

Ключевые слова: финансовая безопасность, государственный долг, финансовый кризис, экономическая безопасность, внешний долг, дефицит бюджета, валовой внутренний продукт.

\author{
В. Ф. Стукач ${ }^{1}$, А. С. Байдалинова ${ }^{2}$, Б. А. Сандыбаева ${ }^{3}$ \\ ${ }^{1}$ Омск мемлекеттік педагогикалық университеті П.А. Столыпин атындағы \\ мемлекеттік ауылшаруашылық университеті, Омбы, Ресей Федерациясы; \\ ${ }^{2}$ Қаржы академиясы, Астана, Қазақстан; \\ 3 «Қазақстандық экономика, қаржы және халықаралық сауда университеті», Астана, Қазақстан

\section{ҚАЗАҚСТАННЫН ҚАРЖЫЛЫҚ ҚАУІПСІЗДІГІ}

Аннотация. Мемлекеттің қаржылық қауіпсіздігін қамтамасыз ету - көптеген елдер үшін маңызды міндет. Бұл міндет қаржылық дағдарыстың қауіп-қатерінен басымдыққа айналады. Бұл, әсіресе, қаржы дағдарысы аймағында болғанда, өйткені мұндай жағдай априори қаржы қауіпсіздігінің жоғалуы дегенді білдіреді.

Түйін сөздер: қаржылық қауіпсіздік, мемлекеттік қарыз, қаржы дағдарысы, экономикалық қауіпсіздік, сыртқы борыш, бюджет тапшылығы, жалпы ішкі өнім.

Information about author:

Stukach V. F. - d.e.s., professor, the Omsk state agricultural university after P.A. Stolypin, Omsk, Russian Federation; Email:vic.econ@mail.ru;

Baydalinova A.S. - Doctoral candidate of PhD, JSC Financial Academy, Astana, Kazakhstan; E-mail: aynur.sultanovna@mail.ru;

Sandybayeva B.A. - Master, JSC Kazakh University of Economics, Finance and International Trade, Astana, E-mail: balzhan_s@list.ru 


\section{МАЗМҰНЫ}

Алтыбаева С.М., Савындыков Е.С. Көркем мәтін құрылымындағы мифопоэтикалық модельдеу және мәдени код...... 5 Сембиева Л.М., Мажитов Д.М., Карпиикая М.Е., Хамитова Д.М. Экономиканы жаңғырту жағдайындағы ЕАЭО елдерінің монетарлық жүесінін өзгеруі .....

Құлсариева А.Т., Султанова М.Э., Шайгозова Ж.Н. Фольклор және сәйкестілік: Қазақстанның қазіргі заманғы

мәдениетіндегі тарих, жады және аңыз шығармашылығы ........................................................................................... 19

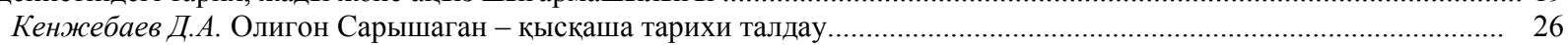

АбдулинаГ.А., БазарбаевА.Г. Ұйымдардағы адам ресурстарын басқарудың заманауи тұжырымдамалары................ 33

Авыбаев А.Н., Адибаева А.К. Геноцид туралы БҰҰ Конвенциясының қатысушы мемлекеттердің қылмыстық

заңнамаларындағы имплементациялық тетіктері: жалпы салыстырмалы талдау............................................................ 39

Ахметжанов Б., Тәжібекова К.Б., Шаметова А.А. Қазақстан көлік өнеркәсіптің дамуын талдау............................. 44

Аюпова 3.К., Құсайынов Д.Ө. Тәуелсіздік жағдайындағы қазақстан республикасының конституциялық-құқықтық

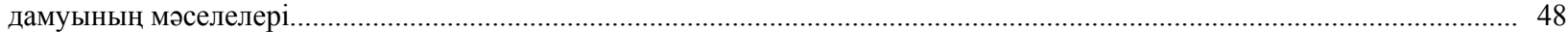

Нурпеисова А.А., Рей И.Ю., Бижанов Д.Т., Тлеужанова Д.А. Инновациялық өндірісді жасаудың процесін

бақылауының негізгі элементтері

Гиздатов Г.Г. Қазақстандық дискурсының құрылымы психолингвистиякалық зерттеу .

Ищанова Р.К. Мемлекеттік шығындарды басқару - мемлекеттің қаржылық тұрақтылығын қамтамасыз ету.............. 64

Мадышева А.М. Бикенова А.С., Елеусиз Л.Т. Білім саласындағы туристік қызметтер............................................. 68

Ескалиева А. Ж., Баймуханова М.Т., Ахмурзина Д.О. Әлеуметтік сала адам капиталының сапасын қолдаудың

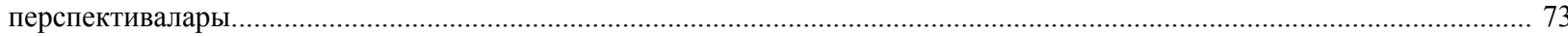

Мархаева Б.А., Козбахова Д.Л. Жауапкершілік орталық және трансферттік баға белгілеу............................................ 79

Сабирова Р.К., Утепкалиева К.М., Кабаков С.Б. Қазақстандағы ауыл шаруашылығы экономикасының

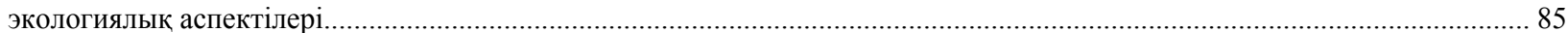

Тлесова Э., Хойч А., Кураш Н. Қазақстан республикасының ғылыми инновациялық потенциясы және оның

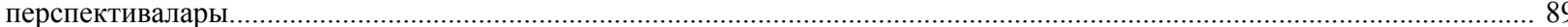

Хамитхан Н. Қазақстандағы банктік қызметтердің сапасын жақсарту жағдайында банкаралык басекелестік............ 95

Шалдарбеков Қ.Б., Муханова Г.С., Нурмухамбетова 3.С. Аймақтарды дамыту бағдарламаларын жүзеге асырудағы жобалық басқаруды қолданудың шетелдік тәжірибесі

КаратаеваА.М., Бердиярова Ж.С. Мемлекеттік қызметшінің әдептік мәдениеті және құқықтық мәдениеті

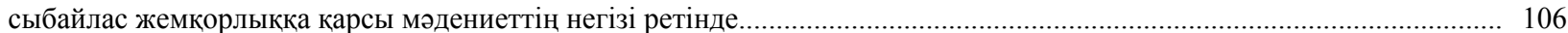

Алдабергенова А.А. Абсурд әдебиетін аударудың лингвомәдени аспектілері ................................................... 113

Стукач В. Ф., Байдалинова А. С., Сандыбаева Б. А. Қазақстанның қаржылық қауіпсіздігі......................................... 119

Баймаханова Д.М., Оспанова Д.А. Конституциялық-құқықтық сана - конституционализмнің маңызды

компоненті ретінде және оның адам құқықтары мәселелерін шешудегі рөлі................................................................. 126

Имангожина 3.А. Сланцевая революция: глобальный тренд на мировом энергетическом рынке............................. 137

Ракаева А.Н., Жуматаева Б.А., Успамбаева М.К., Доскалиева Б.Б. Экологиялық есеп қазақстандағы кәсіпорын экономикасының даму кезеңі ретінде

Нуржанова Г.И. Экономиканың аграрлық секторындағы еңбек әлеуетіне демографиялық фактордың әсері............ 147

Оспанова Д.А., Баймаханова Д.М. Қазақстан Республикасының кибер кеңістігін дамыту жағдайында мемлекеттік қызметтерді цифрландыруда әкімшілік-құқықтық қамтамасыз ету ................................................................................... 152

Pblсnекова М.О., Тлесова Э.Б., Хаитбаева Ф.К. Қазақстандағы тұрғын үй-коммуналдық шаруашылық қызметін

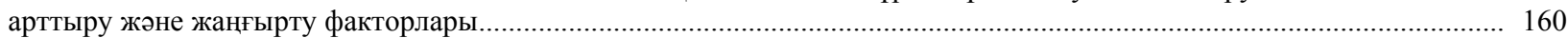

Султанова Г. Т. Аграрлық сектордың экспорттық әлеуетін дамытуға бағытталған үрдістер мен басымдықтар........ 166 


\section{СОДЕРЖАНИЕ}

Алтыбаева С.М., Сагындыков Е.С. Культурный код и мифопоэтическое моделирование в структуре художественного текста.

Сембиева Л.М., Мажитов Д.М., Карпиикая М.Е., Хамитова Д.М. Трансформация монетарной системы стран

ЕАЭС в условиях модернизации экономики.............................................................................................................

Кулсариева А.T., Султанова М.Э., Шайгозова Ж.Н. Фольклор и идентичность: история, память и мифотворчество

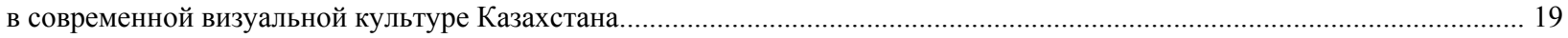

Кенжебаев Д.А. Полигон Сарышаган - краткий исторический анализ................................................................ 26

Абдулина Г.А., БазарбаевА.Г. Современные концепции управления человеческми ресурсами в организациях........... 33

Агыбаев А.Н., Адибаева А.К. Имплементационные механизмы Конвенции ООН о геноциде в уголовных

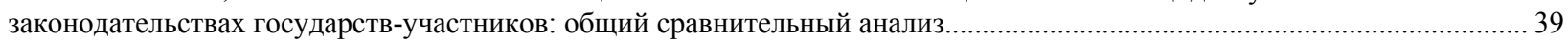

Ахметжанов Б., Тажибекова К.Б., Шаметова А.А. Анализ развития угольной промышленности Казахстана........... 44

Аюпова 3.К., Кусаинов Д.У.Проблемы конституционно-правового развития республики Казахстан в условиях

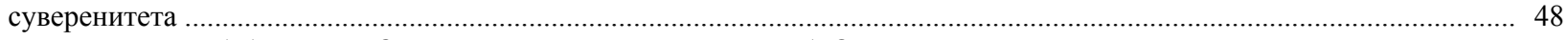

Нурпеисова А.А., Рей И.Ю., Бижанов Д.Т., Тлеужанова Д.А. Основные элементы управления процессом создания

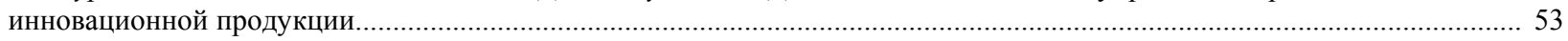

Гиздатов Г.Г. Психолингвистическое исследование концептов казахстанского дискурса...................................... 57

Ищанова Р.К. Управление государственными расходами - как обеспечение финансовой устойчивости государства. 64

Мадымева А.М. Бикенова А.С., Елеусиз Л.Т. Туристские услуги в сфере образования........................................... 68

Ескалиева А. Ж., Баймуханова М.Т., Ахмурзина Д.О. Перспективы усиления качества человеческого капитала

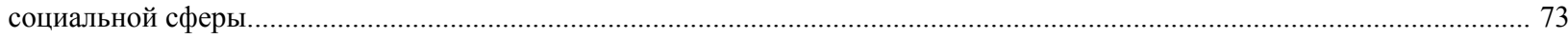

Мархаева Б.А., Козбахова Д.Л. Центр ответственности и трансфертное ценообразование..................................... 79

Сабирова Р.К., Утепкалиева К.М., Кабаков С.Б. Экологические аспекты экономики сельского хозяйства

в Казахстане........................................... 85

Тлесова Э., Хойч А., Кураш Н. Научно-инновационный потенциал республики Казкастан и его перспективы............ 89

Хамитхан Н. Межбанковская конкуренция в условиях повышения качества банковских услуг в Казахстане.............. 95

Шалдарбеков К.Б., Муханова Г.С., Нурмухамбетова 3.С. Зарубежный опыт применения проектного управления

при реализации программ развития регионов

Каратаева А.М., Бердиярова Ж.С. Этическая культура и правовая культура государственных служащих

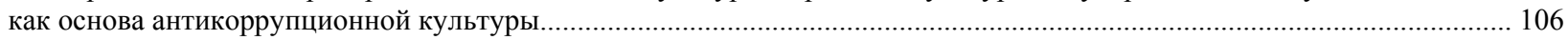

Алдабергенова А.А. Лингвокультурологические аспекты перевода литературы абсурда.......................................... 113

Стукач В. Ф., Байдалинова А. С., Сандыбаева Б. А. Казахстанская финансовая безопасность.................................... 119

Баймаханова Д.М., Оспанова Д.А. Конституционно-правовое сознание как важный компонент конституционализма

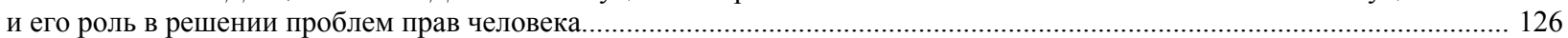

Имангожина 3.A. Сланцевая революция: глобальный тренд на мировом энергетическом рынке............................. 137

Ракаева А.Н., Жуматаева Б.А., Успамбаева М.К., Доскалиева Б.Б. Экологический учет как ступень развития

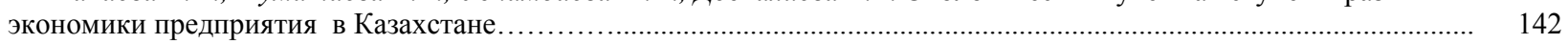

Нуржанова Г.И. Влияние демографического фактора на трудовой потенциал аграрного сектора экономики............ 147

Оспанова Д.А., Баймаханова Д.М. Административно-правовое обеспечение цифровизации государственных услуг

в условиях развития кибер пронстранства республики Казахстан..

Pыспекова М.О., Тлесова Э.Б., Хаитбаева Ф.К. Факторы инновационной модернизации и совершенствования

деятельности жилищно-коммунального хозяйства в Казахстане.

160

Султанова Г. Т. Тенденции и приоритеты развития экспортного потенциала аграрного сектора................................ 166 


\section{CONTENTS}

Altybayeva S.M., Sagyndykov E.S. Cultural code and myth poetic modeling in the structure of the artistic text..................... 5 Sembiyeva L.M., Mazhitov D.M., Karpitskaya M.E., Khamitova D.M. Transformation of the monetary system of the eurasian economic UNION countries in the conditions of modernization of the economy......

Kulsarieva A.T., Sultanova M.E., Shaigozova Zh.N. Folklore and identity: history, memory and myth-making in the modern

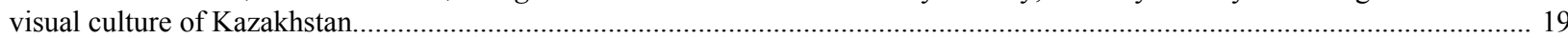

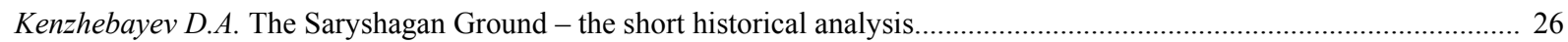

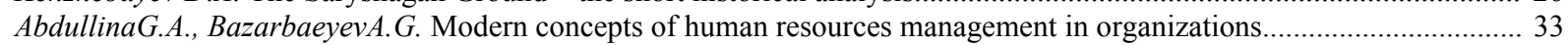

Agybayev A.N., Adibayeva A.K. Implementing mechanisms of the UN Convention on genocide in the criminal legislation

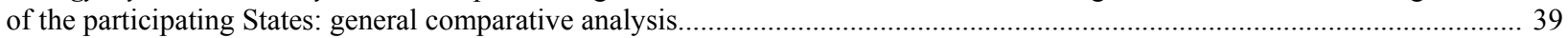

Akhmetzhanov B., Tazhibekova K.B, Shametova A.A. Analysis of development of the coal industry of Kazakhstan.............. 44 Ayupova Z.K., Kussainov D.U. Problems of constitutional and legal development of the republic of kazakhstan in the conditions of sovereignty......

Nurpeisova A.A., Rey I.Yu., Bizhanov D.T., Tleuzhanova D.A. Main elements of managing the process of creating innovation production.

Gizdatov G.G. Psycholinguistic study of the concepts of Kazakhstar

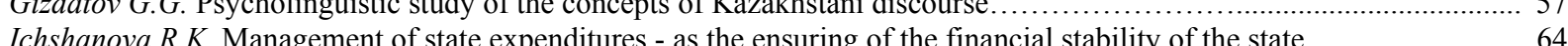

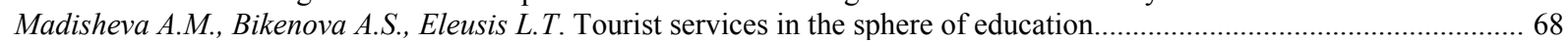

Eskalieva A. Zh., Baymukhanova M.T., Ahmurzina D.O. Perspectives of strengthening the quality of the human capital

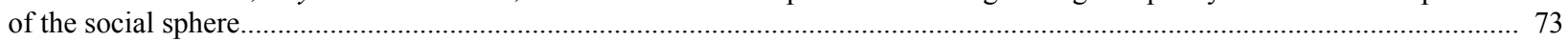

Markhayeva B.A., Kozbakhova D.L. A responsibility center and transfer pricing ................................................. 79

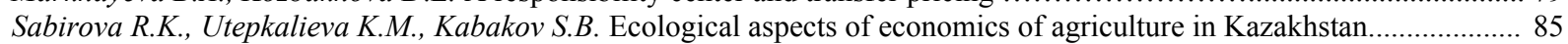

Tlessova E., Khoich A., Kurash N. Scientific innovation potential of the republic of Kazkahstan and its perspectives........ 89

Hamitkhan $N$. Interbank competition in conditions of improving the quality of banking services in Kazakhstan.................. 95

Shaldarbekov K., Mukhanova G., Nurmukhambetova Z. International practices in project management in implementing

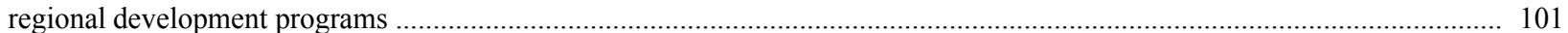

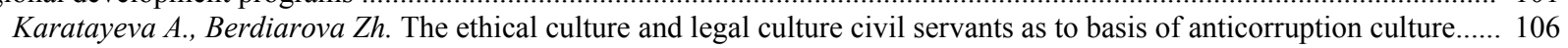

Aldabergenova A.A. Linguocultural aspects of translation of absurd literature.............................................................. 113

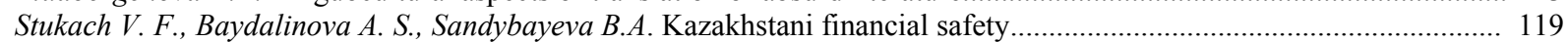

Baimakhanova D.M., Ospanova D.A. Constitutional and legal consciousness as an important component of constitutionalism

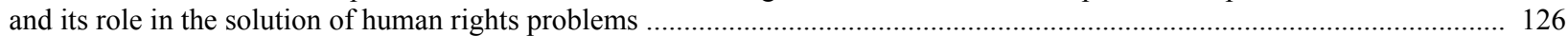

Imangozhina Z.A. Shale gas revolution: global trend in the world energy market..................................................... 137

Rakaeva A.N., Zhumataeva B.A., Uspanbayeva M.K., B.B.Doskalieva. Level of ecological report development in the economic of Kazakhstan's companies.

Nurzhanova G.I. Impact of demographic factors on labor potential of economy's agricultural sector

Ospanova D.A., Baimakhanova D.M. Administrative and legal support of digitalization of public services in the context of the development of cyber space in the republic of Kazakhstan....

Ryspekova M.O., Tlessova E.B., Khaitbayeva F. Factors of innovative modernization and improvement of activity

of housing and communal services in Kazakhstan.

Sultanova G. T. Trends and priorities for the development of export potential of the agrarian sector. 


\title{
PUBLICATION ETHICS AND PUBLICATION MALPRACTICE IN THE JOURNALS OF THE NATIONAL ACADEMY OF SCIENCES OF THE REPUBLIC OF KAZAKHSTAN
}

For information on Ethics in publishing and Ethical guidelines for journal publication see http://www.elsevier.com/publishingethics and http://www.elsevier.com/journal-authors/ethics.

Submission of an article to the National Academy of Sciences of the Republic of Kazakhstan implies that the work described has not been published previously (except in the form of an abstract or as part of a published lecture or academic thesis or as an electronic preprint, see http://www.elsevier.com/postingpolicy), that it is not under consideration for publication elsewhere, that its publication is approved by all authors and tacitly or explicitly by the responsible authorities where the work was carried out, and that, if accepted, it will not be published elsewhere in the same form, in English or in any other language, including electronically without the written consent of the copyrightholder. In particular, translations into English of papers already published in another language are not accepted.

No other forms of scientific misconduct are allowed, such as plagiarism, falsification, fraudulent data, incorrect interpretation of other works, incorrect citations, etc. The National Academy of Sciences of the Republic of Kazakhstan follows the Code of Conduct of the Committee on Publication Ethics (COPE), and follows the COPE Flowcharts for Resolving Cases of Suspected Misconduct (http://publicationethics.org/files/u2/New Code.pdf). To verify originality, your article may be checked by the originality detection service Cross Check http://www.elsevier.com/editors/plagdetect.

The authors are obliged to participate in peer review process and be ready to provide corrections, clarifications, retractions and apologies when needed. All authors of a paper should have significantly contributed to the research.

The reviewers should provide objective judgments and should point out relevant published works which are not yet cited. Reviewed articles should be treated confidentially. The reviewers will be chosen in such a way that there is no conflict of interests with respect to the research, the authors and/or the research funders.

The editors have complete responsibility and authority to reject or accept a paper, and they will only accept a paper when reasonably certain. They will preserve anonymity of reviewers and promote publication of corrections, clarifications, retractions and apologies when needed. The acceptance of a paper automatically implies the copyright transfer to the National Academy of sciences of the Republic of Kazakhstan.

The Editorial Board of the National Academy of sciences of the Republic of Kazakhstan will monitor and safeguard publishing ethics.

Правила оформления статьи для публикации в журнале смотреть на сайте:

$$
\begin{gathered}
\text { www:nauka-nanrk.kz } \\
\text { social-human.kz }
\end{gathered}
$$

\author{
Редакторы М.С. Ахметова, Т.А. Апендиев, Д.С. Аленов \\ Верстка на компьютере А.М. Кульгинбаевой \\ Подписано в печать 10.10.2018 \\ Формат 60x881/8. Бумага офсетная. Печать - ризограф. \\ 11,6 п.л. Тираж 500. Заказ 5.
}

